\title{
A Comparison of Anxiety Level and Nutritional Habits of University Students During Exam and Non-Exam Periods
}

\author{
Indrani Kalkan ${ }^{1, *}$, Büşra Selamet ${ }^{1}$, Çağla Sanem Karakoca ${ }^{1}$, Melike \\ Kumaş ${ }^{1}$, Melisa Düşmez ${ }^{1}$, Şevval Ayaşan ${ }^{1}$
}

\begin{abstract}
Objective: Stress and anxiety play an active role in determining the nutritional habits of an individual. This study was aimed to determine the relation between anxiety levels and nutritional habits of university students during exam and nonexam periods.
\end{abstract}

Methods: The study was conducted on a total of 259 students (131 females and 128 males) enrolled in the first grade of the Faculty of Health Sciences in a private university in Istanbul, during the 2019-2020 academic year. Participants' energy and macro-nutrient consumption were calculated using BeBis software program (8.1 version) and 3-day food consumption records. Turkish version of State-Trait Anxiety Inventory was used to analyse the anxiety levels. Obtained data was evaluated by SPSS (22.0 version) statistical package program. Anova and t-test were applied to determine the difference between energy and food consumption between the two genders during exam and non-exam periods $(\mathrm{p}<0.05)$.

Results: While there was no significant difference between number of meals consumed in a day or skipping of meals between males and females ( $p>0.05)$, breakfast was the most skipped meal $(28.96 \%)$, the most common reason being lack of time $(20.46 \%)$. Percent of energy coming from carbohydrates, fats and proteins did not show a gender difference during examination times $(p>0.05)$. However, in normal times, males were found to consume more fats and proteins whereas females consumed more carbohydrates $(p<0.05)$. Frequency of consumption of tea-coffee, sugary and fried foods increased prior to examination period $(\mathrm{p}<0.001)$. State Anxiety Scores (SAI) decreased by 11 points during

\footnotetext{
${ }^{1}$ Istanbul Aydin Universtity, Department of Nutrition and Dietetics, Istanbul, Turkey

* Corresponding Author

Indrani Kalkan indranikalkan@aydin.edu.tr ORCID: 0000-0001-6020-349X

* Received: 31 March 2021 Accepted: 1 June 2021

DOI: 10.17932/EJOH.2020.022/ejoh_v02i1005
} 
A Comparison of Anxiety Level and Nutritional Habits of University Students During Exam and Non-Exam Periods

examination period in general (mean $=34.08 \pm 8.58)$. State and trait anxiety scores were significantly higher in females $(\mathrm{p}<0.05)$.

Conclusion: Students consumed energy dense foods during/prior to examination periods related to anxiety levels. Providing students with adequate knowledge regarding balanced nutrition and psychological support during stressful periods are important for physical, spiritual and social development.

Keywords: Anxiety Scale, Nutrition, Nutritional Habits, Exam Period, Non-Exam Period,

\section{Introduction}

Adequate and balanced nutrition is very important in young adults due to rapid physical growth as well as pubertal and cognitive development. Food habits in young adults such as university students are different from general population due to time constraints, peer influence, palatability and therefore prefer foods which are easy to access, economic, tasty and easy to prepare (1). Unhealthy food habits as skipping of meals, high intake of sugary beverages, fried and salty food and low intake of fresh vegetables, wholegrains and legumes have led to increased incidence of obesity and other health problems in young adults in recent years (2). Females were more likely to choose healthier foods as fresh fruits and vegetables in accordance with their higher nutrition literacy status as compared to males $(3,4)$. However, in other cases females tended to consume more carbohydrates, fatty foods or snack items under stress as compared to males $(5,6)$. Males on the other hand were likely to purchase alcoholic or energy beverages $(7,8)$. Economic factors and education levels were also reported to affect health behaviors as eating habits, physical activity, smoking and consumption of alcohol and drugs in young individuals (9). Therefore, it may be suggested that nutritional habits in young adults may be negatively influenced by various genetic, sociodemographic, and environmental factors.

Anxiety is defined as the emotion experienced when an individual encounters a new situation and does not know how to react to it (10). Anxiety was reported to affect an individual both physiologically and psychologically. Examination or test anxiety was encountered widely among young individuals especially if the success was related to their career choices and opportunities. While intermediate exam anxiety positively affected academic success, high-level anxiety was found to have negative effects on it (11). Although test anxiety is managed differently among individuals, it is found to affect food habits, physical activity, smoking, drinking and caffeine consumption in young adults. In addition, increased consumption of foods rich in carbohydrates and fat content whereas decreased 
Indrani Kalkan, Büşra Selamet, Çağla Sanem Karakoca, Melike Kumaş, Melisa Düşmez,

Şevval Ayaşan

consumption of fruits and vegetables was noted among students leading to weight gain during these periods $(11,12)$.

This study was aimed to determine the relation between anxiety levels and nutritional habits of university students during exam and non-exam periods.

\section{Methods}

\section{Study Participants}

The study was conducted on a total of 259 students (131 females and 128 males) enrolled in the first grade of the Faculty of Health Sciences in a private university in Istanbul, Turkey during the 2019-2020 academic year. The study was conducted between January 2020-March 2020. Care was taken to enable a uniform distribution with respect to the students' gender and fields of study (Nutrition and Dietetics, Nursing, Physiotherapy, Health Management, Social Services, Child Development, Odiology). The total population of students enrolled in the Faculty of Health Sciences in the academic year 2019-2020 were 760 approximately. The experimental sample was calculated to be 255 according to stratified sampling method (confidence level 95\%, margin of error 5\%). The participants were selected on a random basis after taking their voluntary approval.

\section{Ethical issues}

The study was conducted in accordance with ethical standards of the responsible committee on human experimentation (institutional and national) and with Helsinki Declaration. Ethical approval for this study was acquired by the university's ethical committee dated on January 14, 2020 (Document No: B.30. AYD.0.00.00-500.06.04/220-2019/152).

\section{Data Collection}

Data was collected by a means of a questionnaires conducted by face-to-face interview technique.

\section{Demographic Information Form}

The individuals were asked to fill in general information about themselves as sex, age, weight $(\mathrm{kg})$, height $(\mathrm{m})$ and the department of the faculty that they were enrolled in. Body Mass Index (BMI was calculated from body weight and height measurements using the formula body weight / height2). BMI was assessed as per below: (15) 
A Comparison of Anxiety Level and Nutritional Habits of University Students During Exam and Non-Exam Periods

$\mathrm{BMI}<18 \mathrm{~kg} / \mathrm{m}^{2}$ : underweight

$18<$ BMI $<24.99 \mathrm{~kg} / \mathrm{m}^{2}$ : normal weight

$24.99<\mathrm{BMI}<29.99 \mathrm{~kg} / \mathrm{m}^{2}$ : overweight-slightly obese

\section{Dietary Habits}

In the dietary habits section, questions related to eating habits of an individual were examined, such as the number of meals consumed per day, skipping meal habits, preferences of food types at meals, food preferences during examination periods. In addition, during the examination period and non-examination period. Food consumption frequency and a 3-day food consumption record was taken for all individuals during examination and normal periods, to calculate and compare the macro and micro-nutrients during these periods. The book "Food and Food Photo Catalog: Measures and Amounts" was used to determine the portions and amounts of foods consumed.

The participants were also questioned regarding their appetite (hunger and desire to eat) during meals in order to evaluate the reason for skipping meals. In addition, the students were also asked about consumption of caffeinated beverages and cigarettes during normal and examination periods.

Using the food consumption records, macro and micro-nutrients intake amounts were calculated using the BeBiS (Nutrition Information Systems) program.

\section{Measurement of Anxiety: State Trait Anxiety Inventory (STAI)}

Turkish version (Oner and Le Compte, 1983) of State-Trait Anxiety Inventory (STAI) (Spielberger et al, 1970) was used to analyse the anxiety levels of participants. The tool comprised of two sub-scales each consisting of 20 items evaluating state (SAI) and trait (TAI) anxiety levels using 4-point likert scale (not at all, somewhat, moderately so, very much so). The first part of the scale (SAI) indicated the anxiety level of the individual at that moment ("I am calm right now") and the responses were scored as $1=$ Not at all, 2=Somewhat, $3=$ Moderately so, $4=$ Very much so. The second part of the scale (TAI) indicated the continuous anxiety levels ("Usually I am in the mood") of individuals with the same kind of likert scale, however, the responses were scored as $0=$ not at all, $1=$ Somewhat, $2=$ Moderately so, $3=$ Very much so, respectively. Total scores vary between 20-80 points and higher scores indicated greater degree of anxiety.

\section{Statistical Analysis}

Obtained data were analyzed by the SPSS 22.0 software program. The means, standard deviations, frequencies and percentage values of demographic variables, 
Indrani Kalkan, Büşra Selamet, Çağla Sanem Karakoca, Melike Kumaş, Melisa Düşmez,

Şevval Ayaşan

STAI scores and intake of nutrients by participants were calculated. As the data was found to be normally distributed, t-test and one-way analysis of variance (ANOVA) were applied to measure the effect of demographic data on the scales. Independent t-test was applied to compare the data between males and females for nutritient intakes and STAI scores during exam and non-exam periods. Level of significance was defined as $\mathrm{p}<0.05$.

\section{Results}

The study was conducted on 259 students ( 131 females, 128 males) whose average age was calculated as $21.31 \pm 1.49$ years. Mean height and weight of female participants were found to be $165.98 \pm 5.96 \mathrm{~cm}$ and $59.21 \pm 10.20 \mathrm{~kg}$, whereas for males the values were $179.37 \pm 6.74 \mathrm{~cm}$ and $78.00 \pm 11.77 \mathrm{~kg}$ respectively. On categorizing the participants according to BMI ranges, $17.1 \%$ of participants were in the $24.99-29.99$ range considered to be overweight or slightly obese. On the other hand, $67.6 \%$ of the participants were within BMI range of $19.0-24.99$ and were considered normal.

Food habits of participants were enquired and recorded as per statements during non-exam periods. On enquiring about the number of meals that participants consumed in a day, $31.7 \%$ stated that they consumed three meals, $29.3 \%$ four meals and $10.2 \%$ consumed two meals in a day. Gender difference was not found to be significant ( $>0.05$ ). 56.8\% of participants spent more than $500 \mathrm{TL}$ and $30.9 \%$ spent $250-500 \mathrm{TL}$ for personal food expenditures in a month. Regarding appetite during meals, \%50.4 stated that they had adequate appetite whereas $45.6 \%$ mentioned that they lacked appetite during certain meals. Most of the participants (57.1\%) drank 6-10 cups of water whereas $18.9 \%$ consumed more than 10 cups and 23.9 consumed less than 5 cups of water in a day.

Of the participants, $76.4 \%$ consumed $1-5$ cups of other beverages whereas $18.1 \%$ did not consume any other beverage apart from water. $96.1 \%$ of the student ate outside, $63.3 \%$ ate outside on 1-5 days, $20.5 \%$ 6-10 days, $12.7 \%$ on more than 10 days in a month. Regarding meals eaten outside, 59.07\% ate lunch and $42.86 \%$ ate dinner outside. $63.0 \%$ of the students preferred fast food whereas $19.8 \%$ preferred home-made meals. Regarding eating late nights or on waking up in the middle of night, $39 \%$ responded negatively whereas $31.3 \%$ mentioned that they did so sometimes and $29.7 \%$ mentioned that they did it on a regular basis. Regarding vitamin and mineral supplements, $64.9 \%$ replied in negative, $14.7 \%$ sometimes took supplements $20.5 \%$ took supplements on a regular basis.

Regarding skipping of meals, $67.2 \%$ of females and $69.5 \%$ of male participants stated to skipped at least one meal in a day. Breakfast was the 
A Comparison of Anxiety Level and Nutritional Habits of University Students During Exam and Non-Exam Periods

most skipped meal (38.22\%) followed by lunch (35.14\%). The main reason for skipping meals stated by both genders was lack of time (39.0\%) followed by lack of appetite (14.29\%).

All the above questioned were repeated to the participants during exam periods. Independent t-test and ANOVA were performed to compare and evaluate the responses provided by males and females at two different times (exam and non-exam) to understand the effect of exam related anxiety on the food habits of participants (Table 2).

On analysing the snacking habits of participants, carbonated sugary drinks were the most consumed beverage (40.15\%) followed by buttermilk (31.66\%). Chocolates were found to be the most consumed item (54.83\%) followed by nuts $(44.79 \%)$, fruits $(42.47 \%)$ and cookies $(40.54 \%)$. Table 1 shows energy, carbohydrate $(\mathrm{CHO})$, protein and fat consumption of participants in normal times.

Table 1. Energy, CHO, Protein and Fat consumption during non-exam times

\begin{tabular}{|c|c|c|c|c|c|c|}
\hline & Gender & $\mathrm{N}$ & Mean & S.D. & $\mathrm{t}$ & $\mathrm{p}$ \\
\hline \multirow{2}{*}{$\begin{array}{l}\text { E n e r j i } \\
(\mathrm{kcal})\end{array}$} & Female & 131 & 1390.57 & 388.67755 & 2.022 & 0.44 \\
\hline & Male & 128 & 1283.51 & 459.64735 & & \\
\hline \multirow[t]{2}{*}{$\mathrm{CHO}(\mathrm{g})$} & Female & 131 & 159.587 & 56.92048 & 3.643 & $0.000 *$ \\
\hline & Male & 128 & 134.976 & 51.71989 & & \\
\hline \multirow{2}{*}{$\begin{array}{l}\text { C H O } \\
(\%)\end{array}$} & Female & 131 & 46.6641 & 7.11727 & 6.094 & 0.000 * \\
\hline & Male & 128 & 39.2422 & 11.84795 & & \\
\hline \multirow{2}{*}{$\begin{array}{l}\text { Protein } \\
\text { (g) }\end{array}$} & Female & 131 & 57.3198 & 19.87399 & 0.855 & 0,393 \\
\hline & Male & 128 & 55.0914 & 22.04717 & & \\
\hline \multirow{2}{*}{$\begin{array}{l}\text { Protein } \\
(\%)\end{array}$} & Female & 131 & 16.4427 & 3.02594 & -3.230 & $0.001 *$ \\
\hline & Male & 128 & 17.6313 & 2.89506 & & \\
\hline \multirow[t]{2}{*}{ Fat (g) } & Female & 131 & 56.2061 & 18.08225 & -0.639 & 0,523 \\
\hline & Male & 128 & 58.3313 & 33.37331 & & \\
\hline \multirow[t]{2}{*}{ Fat (\%) } & Female & 131 & 36.5344 & 5.85767 & -3.031 & $0.003 *$ \\
\hline & Male & 128 & 38.9344 & 6.83438 & & \\
\hline
\end{tabular}

Regarding consumption of alcoholic and caffeinated beverages, $90.7 \%$ of participants consumed coffee, $90.6 \%$ tea and $50.6 \%$ alcohol on an occasional basis. $80.7 \%$ of the students stated that they consumed 1-5 cups of coffee in a day, $69.9 \%$ stated consuming $1-5$ cups of tea on a daily basis. Regarding alcohol, $80 \%$ of the students consumed alcohol 1-5 days in a month and $12.3 \%$ consumed 6-10 days in a month. 
Indrani Kalkan, Büşra Selamet, Çağla Sanem Karakoca, Melike Kumaş, Melisa Düşmez,

On conducting the State Anxiety Inventory (SAI) during non-exam time, mean SAI score of participants was calculated as $34.08 \pm 8.58$ (Minimum 16 Maximum 71). The scores were found to be 11 points lower than those calculated during exam times. Independent t-test was conducted to evaluate the difference between scores obtained by male and female participants. SAI score was found to be significantly higher in females during both exam and non-exam times $(p<0.05)$.

Table 2 compares food habits, macro-nutrient intakes and SAI scores of male and female participants during exam and non-exam periods.

Table 2. Food habits, macro-nutrient intakes and SAI scores of participants

\begin{tabular}{|c|c|c|c|c|c|c|}
\hline Items & & $\mathrm{N}$ & Mean & S.D. & $\mathrm{t}$ & $\mathrm{p}$ \\
\hline \multirow{2}{*}{$\begin{array}{l}\text { Amount (TL) } \\
\text { spent on food per } \\
\text { month }\end{array}$} & Exam Period & 259 & 2.44 & 0.70 & 0.885 & 0.377 \\
\hline & $\begin{array}{l}\text { Non-Exam } \\
\text { Period }\end{array}$ & 259 & 2.39 & 0.69 & & \\
\hline \multirow{2}{*}{$\begin{array}{l}\text { Number of meals } \\
\text { consumed in a day }\end{array}$} & Exam Period & 259 & 3.76 & 1.14 & -1.678 & 0.094 \\
\hline & $\begin{array}{l}\text { Non-Exam } \\
\text { Period }\end{array}$ & 259 & 3.93 & 1.06 & & \\
\hline \multirow[b]{2}{*}{ Skipping Meals } & Exam Period & 259 & 1.32 & 0.47 & -0.279 & 0.780 \\
\hline & $\begin{array}{l}\text { Non-Exam } \\
\text { Period }\end{array}$ & 256 & 1.33 & 0.47 & & \\
\hline \multirow[b]{2}{*}{ Appetite } & Exam Period & 258 & 1.53 & 0.57 & 0.571 & 0.568 \\
\hline & $\begin{array}{l}\text { Non-Exam } \\
\text { Period }\end{array}$ & 259 & 1.51 & 0.59 & & \\
\hline \multirow{2}{*}{$\begin{array}{l}\text { Cups of water } \\
\text { consumed in a day }\end{array}$} & Exam Period & 259 & 1.95 & 0.65 & -0.477 & 0.633 \\
\hline & $\begin{array}{l}\text { Non-Exam } \\
\text { Period }\end{array}$ & 259 & 1.98 & 0.63 & & \\
\hline \multirow{2}{*}{$\begin{array}{l}\text { Other beverages } \\
\text { (Cups) consumed } \\
\text { in a day }\end{array}$} & Exam Period & 259 & 0.87 & 0.47 & -0.184 & 0.854 \\
\hline & $\begin{array}{l}\text { Non-Exam } \\
\text { Period }\end{array}$ & 259 & 0.88 & 0.49 & & \\
\hline \multirow{2}{*}{$\begin{array}{l}\text { Eating of meals } \\
\text { outside }\end{array}$} & Exam Period & 256 & 1.04 & 0.19 & 0.027 & 0.979 \\
\hline & $\begin{array}{l}\text { Non-Exam } \\
\text { Period } \\
\end{array}$ & 259 & 1.04 & 0.19 & & \\
\hline \multirow{2}{*}{$\begin{array}{l}\text { Frequency of } \\
\text { meals taken }\end{array}$} & Exam Period & 251 & 1.47 & 0.72 & 2.176 & $0.030 *$ \\
\hline & $\begin{array}{l}\text { Non-Exam } \\
\text { Period }\end{array}$ & 259 & 1.34 & 0.67 & & \\
\hline
\end{tabular}


A Comparison of Anxiety Level and Nutritional Habits of University Students During Exam and Non-Exam Periods

\begin{tabular}{|c|c|c|c|c|c|c|}
\hline \multirow{2}{*}{$\begin{array}{l}\text { Meal consumed } \\
\text { outside }\end{array}$} & Exam Period & 248 & 1.40 & 0.77 & -0.360 & 0.719 \\
\hline & $\begin{array}{l}\text { Non-Exam } \\
\text { Period }\end{array}$ & 259 & 1.42 & 0.82 & & \\
\hline \multirow{2}{*}{$\begin{array}{l}\text { Consumption of } \\
\text { coffee (yes/no) }\end{array}$} & Exam Period & 259 & 1.09 & 0.29 & -1.393 & 0.164 \\
\hline & $\begin{array}{l}\text { Non-Exam } \\
\text { Period }\end{array}$ & 259 & 1.13 & 0.34 & & \\
\hline \multirow{2}{*}{$\begin{array}{l}\text { Cups of coffee } \\
\text { consumed in a day }\end{array}$} & Exam Period & 259 & 1.04 & 0.51 & 1.237 & 0.217 \\
\hline & $\begin{array}{l}\text { Non-Exam } \\
\text { Period }\end{array}$ & 259 & 0.98 & 0.55 & & \\
\hline \multirow{2}{*}{$\begin{array}{l}\text { Consumption of } \\
\text { tea (yes/no) }\end{array}$} & Exam Period & 258 & 1.15 & 0.36 & -0.227 & 0.821 \\
\hline & $\begin{array}{l}\text { Non-Exam } \\
\text { Period }\end{array}$ & 259 & 1.15 & 0.36 & & \\
\hline \multirow{2}{*}{$\begin{array}{l}\text { Cups of coffee } \\
\text { consumed in a day }\end{array}$} & Exam Period & 259 & 1.02 & 0.61 & -0.075 & 0.940 \\
\hline & $\begin{array}{l}\text { Non-Exam } \\
\text { Period }\end{array}$ & 259 & 1.03 & 0.56 & & \\
\hline \multirow{2}{*}{$\begin{array}{l}\text { Consumption of } \\
\text { food before sleep } \\
\text { or middle of night. }\end{array}$} & Exam Period & 259 & 2.02 & 0.78 & -1.766 & 0.078 \\
\hline & $\begin{array}{l}\text { Non-Exam } \\
\text { Period }\end{array}$ & 259 & 2.13 & 0.71 & & \\
\hline \multirow{2}{*}{$\begin{array}{l}\text { Intake of vitamin/ } \\
\text { mineral supple- } \\
\text { ments }\end{array}$} & Exam Period & 259 & 1.94 & 0.59 & -1.882 & 0.060 \\
\hline & $\begin{array}{l}\text { Non-Exam } \\
\text { Period }\end{array}$ & 259 & 2.04 & 0.58 & & \\
\hline \multirow[b]{2}{*}{ Energy (kcal) } & Exam Period & 257 & 1374.62 & 485.12 & 0.918 & 0.359 \\
\hline & $\begin{array}{l}\text { Non-Exam } \\
\text { Period }\end{array}$ & 259 & 1337.67 & 427.78 & & \\
\hline \multirow[b]{2}{*}{$\mathrm{CHO}(\mathrm{g})$} & Exam Period & 257 & 213.37 & 917.71 & 1.154 & 0.249 \\
\hline & $\begin{array}{l}\text { Non-Exam } \\
\text { Period }\end{array}$ & 259 & 147.42 & 55.69 & & \\
\hline \multirow[b]{2}{*}{$\mathrm{CHO}(\%)$} & Exam Period & 257 & 46.74 & 8.34 & 4.505 & $0.000 *$ \\
\hline & $\begin{array}{l}\text { Non-Exam } \\
\text { Period }\end{array}$ & 259 & 43.00 & 10.41 & & \\
\hline \multirow[b]{2}{*}{ PRO (g) } & Exam Period & 257 & 54.15 & 19.99 & -1.149 & 0.251 \\
\hline & $\begin{array}{l}\text { Non-Exam } \\
\text { Period }\end{array}$ & 259 & 56.22 & 20.97 & & \\
\hline \multirow[b]{2}{*}{ PRO (\%) } & Exam Period & 257 & 16.35 & 3.62 & -2.331 & $0.020 *$ \\
\hline & $\begin{array}{l}\text { Non-Exam } \\
\text { Period }\end{array}$ & 259 & 17.03 & 3.02 & & \\
\hline
\end{tabular}


Indrani Kalkan, Büşra Selamet, Çağla Sanem Karakoca, Melike Kumaş, Melisa Düşmez,

\begin{tabular}{lllllll}
\hline \multirow{2}{*}{ LIPID (g) } & Exam Period & 257 & 57.03 & 22.37 & -0.104 & 0.917 \\
\cline { 2 - 7 } & $\begin{array}{l}\text { Non-Exam } \\
\text { Period }\end{array}$ & 259 & 57.26 & 26.72 & & \\
\hline $\begin{array}{l}\text { SAI (State Anxi- } \\
\text { ety Inventory) }\end{array}$ & Exam Period & 259 & 45.22 & 12.61 & 11.745 & $\mathbf{0 . 0 0 0 *}$ \\
\cline { 2 - 7 } & $\begin{array}{l}\text { Non-Exam } \\
\text { Period }\end{array}$ & 259 & 34.08 & 8.58 & & \\
\hline
\end{tabular}

$* \mathrm{p}<0.05$ (significant)

As per results, AI scores of all participants, frequency of meals and $\mathrm{CHO}$ $\%$ were consumed significantly higher during exam times $(\mathrm{p}<0.05)$. On the other hand, percentage of protein consumed was significantly lower during exam time $(\mathrm{p}<0.05)$. (Table 2)

On comparing the SAI scores obtained by males $(47.03 \pm 12.76)$ and females (44.42 \pm 12.45$)$, no significant difference was found among the means of the two $(\mathrm{p}>0.05)$.

Table 3 below shows the Trait Anxiety Inventory (TAI) scores for male and female participants. This score indicates the continuous stress levels of the participants. Mean score obtained by the students was found to be $39.23 \pm 9.13$. The lowest score was 4 and the highest score was 67. Mean TAI score of females was $41.01 \pm 9.97$ whereas for males the score was $37.42 \pm 7.80$. As per the results, TAI scores were found to be significantly higher in females. $(p<0.05)$ (Table 3$)$

Table 3. TAI scores of Male and Female Participants

\begin{tabular}{lllllll}
\hline & Gender & $\mathrm{N}$ & Mean & S.D. & $\mathrm{t}$ & $\mathrm{p}$ \\
\hline \multirow{2}{*}{ TAI Scores } & Female & 131 & 41.01 & 9.97 & 3.226 & 0.001 \\
\cline { 2 - 7 } & Male & 128 & 37.42 & 7.80 & & \\
\hline
\end{tabular}

Food consumption frequency of certain foods as milk products, meat, fruits and vegetables, grains, tea, coffee, cereals, legumes, sugary items, fatty and fried foods and energy beverages during exam periods and non-exam periods were enquired to the participants. Consumption of tea, coffee $(63 \%)$, fatty fried foods $(48.6 \%)$ and sugary items (64.1\%) increased substantially during exam periods. On the other hand, consumption of fruits, vegetables, meat and milk products, legumes and grains were not affected during exam and non-exam periods.

\section{Discussion}

The prevalence of obesity in Turkish adolescents have increased from $0.6 \%$ to $7.3 \%$ with an 11.6-fold increase between the periods $1990-1995$ to 2011-2015. 
A Comparison of Anxiety Level and Nutritional Habits of University Students During Exam and Non-Exam Periods

As per the latest Turkish national health survey results, prevalence of obesity has increased in both genders; However, boys were more likely to be obese than girls $(16,17)$. In another study conducted on university students, $33.5 \%$ of males and $24.8 \%$ of females were found to be in overweight range (18). In this study, $17.1 \%$ of the students had a BMI in the 24.99 - 29.99 range of overweight or slightly obese. However, gender difference was not significant ( $p>0.05)$.

In this study, $31.7 \%$ of participants consumed three and $29.3 \%$ four meals in a day, slightly higher than Ayhan et al's study in Bursa Uludag University in which $20.4 \%$ were reported to have consumed three and $5.4 \%$ four meals a day. In this study, there was no gender difference and effect of exam periods on meal consumption was not found to be significant ( $\mathrm{p}>0.05)$ (19).

Normally, $67.2 \%$ of females and $69.5 \%$ of male participants stated to skipped at least one meal in a day. Breakfast was the most skipped meal (38.22\%) followed by lunch (35.14\%) in this study. Similarly, in a study conducted at Atatürk University students in Erzurum, morning meals were reported to be skipped the most and evening meals the least (20). In a study conducted in Ankara by Zemzemoglu et al, the major reason stated by the students $(47.4 \%)$ for skipping meal was lack of time. This finding was similar to results of this study as 39\% state the same reason for skipping meals. Choice of beverages by students in Zemzemoglu et al's study was similar to this study in the sense that coke, tea, coffee, buttermilk were the most popular drinks between meals (21).

In this study, eating outside (96.1\%) and fast-food consumption were high among students (63.3\%) during exam and non-exam times. In another study conducted on university students in Burdur, $62.5 \%$ of participants preferred fast food and $74.1 \%$ ate outside on a regular basis (22).

In this study, while $90 \%$ of the students consumed tea and coffee in general, students stated that they increased consumption of tea and coffee during exam period, in a study, conducted by Budak et al, $80.5 \%$ of the students were reported to consume coffee and $97.4 \%$ black tea (23).

In this study, the energy intake in exam and non-exam periods were $1374.62 \pm 485.12$ and $1337.67 \pm 427.78 \mathrm{kcal}$ respectively. These amounts were comparatively less as compared to a study conducted in Bingol University students where average daily energy intake was reported to be $3175.5 \pm 776.4$ $\mathrm{kcal}$ in men and $2583.8 \pm 703.6 \mathrm{kcal}$ in women. In addition, $44.05 \%$ of the foods consumed by the students contained carbohydrates, $43.35 \%$ fat and $11.5 \%$ protein (24). On comparing with his study however, the consumed $\mathrm{CHO}$, protein and fat percentages of participants were similar. In this study, only carbohydrate $(\%)$ intake increased significantly during exam period $(\mathrm{p}<0.05)$ and protein 
Indrani Kalkan, Büşra Selamet, Çağla Sanem Karakoca, Melike Kumaş, Melisa Düşmez,

(\%) decreased significantly during exam period $(\mathrm{p}<0.05)$. Furthermore, it was observed that women intake less energy than men during the non-examination period, but the amount of carbohydrate that women took in this period was higher than men, and that men consumed more protein than women (Table1). Energy consumption varies to a great extent among young population groups. In a study conducted on 450 students in Ankara preparing for university entrance exam, the mean energy consumption was found to be $1738.2 \mathrm{kcal}$ varying between 696.2 $4294.1 \mathrm{kcal} / \mathrm{d}(25)$.

In this study, the Trait Anxiety Scale (TAI) was used to evaluate the continuous anxiety score of the students. The mean score of the students was found to be $39.23 \pm 9.13$. The lowest score was 4 and the highest score was 67 . The mean TAI score of female students $(41.01 \pm 9.97)$ was significantly higher as compared to males $(37.42 \pm 7.80)(\mathrm{p}<0.05)$ (Table 3$)$. In a similar study conducted on another group of university students, the mean SAI score of students was found to be $57 \pm 5.25$. In the normal period, it was observed that the anxiety levels of men were moderate and the anxiety levels of women were high (26). In this study, SAI scores during non-exam time, mean SAI score of participants was calculated as $34.08 \pm 8,58$. The scores were found to be 11 points lower than those calculated during exam times. SAI score was found to be significantly higher in females during both exam and non-exam times $(\mathrm{p}<0.05)$. In another study conducted by Bayindir et al on-university students preparing for exams, (27) TAI scores of female students were found to be significantly higher (47.2 \pm 6.35$)$ as compared to males $(45.4 \pm 6.85)$. In a study carried out on 4850 university students in Bursa Turkey, $29.6 \%$ and $36.7 \%$ of the students reported state (SAI) and trait (TAI) anxiety scores of more than 45 points, respectively (28).

\section{Conclusion}

Nutritional habits of young adults as university students are affected by several factors as gender, age, socio-demographic characteristics, social circle and so on. Stress and anxiety factors have been found to affect eating habits of students. The study demonstrated that state and trait anxiety levels were higher in females as compared to males in exam and non-exam times. Individuals tended to consume food items as high sugar and fatty fried foods, tea, coffee and other caffeinated beverages during exam times. At the same time students tended to skip meal eat outside and prefer fast food during exam and non-exam periods. Consumption of dairy products, meat, fresh fruits and vegetables, grains and legumes remained unchanged.

Considering the rising obesity among adolescents and youth being a crucial stage for adopting dietary habits that may continue throughout lifetime, 
A Comparison of Anxiety Level and Nutritional Habits of University Students During Exam and Non-Exam Periods

increase in awareness among this age group regarding healthy eating and dietary quality is of special importance from the perspective of health and prevention of obesity related chronic diseases. The evidence stresses on increasing public awareness, recommends health practitioners and policymakers to consider public health strategies and regulations that focus on increasing nutrition education, knowledge and health awareness in the society.

\section{Conflict of Interest and Acknowledgement}

None stated by the authors.

\section{References}

1. Choi J. Impact of stress levels on eating behaviors among college students. Nutrients. 2020;1241: 1-10.

2. Peltzer K, Pengpid S, Samuels TA, Özcan NK, Mantilla C, et al. Prevalence of overweight/obesity and its associated factors among university students from 22 countries. Intl J Environ Res Pub Health. 2014;11(7):7425-7441.

3. Morse KL, Driskell JA. Observed sex differences in fast-food consumption and nutrition self-assessments and beliefs of college students. Nutr Res. 2009; 29:173-179.

4. Kalkan I. The impact of nutrition literacy on the food habits among young adults in Turkey. Nutr Res Prac.2019; 13(4):352-357.

5. Zellner DA, Loaiza S, Gonzalez Z, Pita J, Morales J, et al. Food selection changes under stress. Physiol Behav. 2006;87:789-793.

6. Ross SE, Niebling, BC, Heckert TM. Sources of stress among college students. Coll Students J. 1999;33:312-316.

7. Kalkan I, Pehlivan M, Ozturk SA, Ersoy G. Awareness and usage of sports and energy drinks among university students: A pilot study in Turkey. BLDE Univ J of Health Sci. 2018; 3(1):18-23.

8. Tam R, Yassa, B, Parker, H, O’Connor, H, Allman-Farinelli, M. University students' on-campus food purchasing behaviors, preferences, and opinions on food availability. Nutrition. 2017;37:7-13.

9. Hanson MD, Chen E. Socioeconomic status and health behaviors in adolescence: a review of the literature. J Behav Med. 2007;30:263-285.

10. Kierkegaard S. The Concept of Anxiety: A simple psychologically orientated 
Indrani Kalkan, Büşra Selamet, Çağla Sanem Karakoca, Melike Kumaş, Melisa Düşmez,

deliberation in view of the dogmatic problem of hereditary sin. Translated by A. Hannay. London: W.W Norton.2014.

11. Kurtulus O, Balci UG, Simsek Y, Kucuk H, Fidan E. Anxiety among university students and its effects on nutrition. WONCA Europe Conference, 2015.

12. Schwartz TL, Nihalani N, Jindal S, Virk S, Jones N. Psychiatric medicationinduced obesity: treatment options. Obesity Rev. 2004; 5(2): 233-238.

13. Öner N, Le Comte A. [Süreksiz durumluk/sürekli kaygl envanteri el kitabl, Boğaziçi Üniv. Yayınları.] 1983;1-3.

14. Speilberger CD. State-Trait anxiety inventory for adults. [Database record]. APA PsycTests. 1970, http://www.apa.org/pubs/databases/psyctests/ (Access 24.03.2021)

15. Bundak R. Body mass index references for Turkish children. ACTA Paediatrica. 2007; 95(2):194-198.

16. TÜBER Turkey National and Health Survey 2017, https://dosyasb.saglik. gov.tr/ Eklenti/10915,tuber-turkiye-beslenme-rehberipdf.pdf/ (Access 07.05.2021)

17. Alper Z, Ercan I, Uncu Y. A Meta-analysis and an evaluation of trends in obesity prevalence among children and adolescents in Turkey: 1990 through 2015. J Cli Res Pediatric Endocrinol. 2018;10(1):59-67.

18. Yildirim I, Yıldırım Y, Isık O, Karagoz S, Ersoz Y, Dogan I. Obesity prevalance among university students according to different measurement methods. Inonu Univ J Phy Educ Sports Sci. 2017;4(2):20-33.

19. Ayhan ED, Günaydin E, Gönlüaçik E, Arslan U, Çetinkaya F, Asimi H, Uncu Y. [Uludă̆ Üniversitesi Tip Fakültesi ögrencilerinin beslenme alışkanlıklart ve bunları etkileyen faktörler. Uludağ Üniv Tip Fak Derg.] 2012;38(2): 97104.

20. Vançelik S, Gürsel ÖS, Güraksin A, Beyhun E. [Üniversite öğrencilerinin beslenme bilgi ve alışkanlıkları ile ilişkili faktörler. Tsk Koruyucu Hekimlik Bülteni.] 2007; 6(4):242-248.

21. Zemzemoglu Arpa TE, Erem S, Uludağ E, Uzun S. Determination of nutritional habits among students of Health Sciences Faculty. Food and Health. 2019;5(3):185-196.

22. Orak S, Akgün S, Orhan H. [Süleyman Demirel Üniversitesi ögrrencilerinin beslenme alışkanlıklarının araştırılması. SDÜ Tıp Fakültesi Derg.] 2009; 
A Comparison of Anxiety Level and Nutritional Habits of University Students During Exam and Non-Exam Periods

$$
\text { 13(2):5-11. }
$$

23. Budak N, Çiçek B, Şahin H. [Üniversite ögrencilerinin tükettikleri içecekler ve tercihlerini belirleyen etmenler. Bes ve Diyet Derg.] 2002;31(2):31-40.

24. Erçim RE. Üniversite öğrencilerinin beslenme durumlarının değerlendirilmesi ve sağlıklı yeme indekslerinin saptanması http://www.openaccess.hacettepe. edu.tr: 8080/Xmlui/ Bitstream/Handle/11655/1597/42db39a4-F38c-4a3a94af-Cab520244b9d.Pdf? 2014; (Accessed 26.03.2021).

25. Aslan NN, Yardimci H, Ozcelik AO. Macro nutrient intakes of students preparing for national university exams and its relation with anthropometric measurement. Erciyes University Health Sciemnces Faculty Journal. 2017; 4(1): 39-38.

26. Erdul G. [Üniversite ögrencilerinin zaman yönetimi becerileri ile kayg düzeyi. Uludağ Üniversitesi Yüksek Lisans Tezi.] http://acikerisim.uludag. edu.tr> 2005; (Accessed 26.03.2021).

27. Bayındır G, Yardımc1 H, Keser A. [Sinava hazırlanan ögrencilerin besleme durumlarının kaygı puanlarrına göre değerlendirilmesi. Düzce Üniv. Sağlık Bilimleri Enst Derg.] 2018;8 (1): 22-28.

28. Sakin Ozen N, Ercan I, Irgil E, Sigirli D. Anxiety prevalence and affecting factors among university students. Asia Pacific J Pub Health. 2010;22(1):127133. 